Reprod. Nutr. Dévelop., 1982, 22 (3), 455-463.

\title{
In vivo fertilization after initiation of sperm motility in the hamster epididymis
}

\author{
Marie-Louise KANN, Françoise RAYNAUD \\ Laboratoire de Physiologie de la Reproduction des Vértébrés, Bât. A, \\ Université $P$. et $M$. Curie, 4, place Jussieu, 75230 Paris Cedex 05, France.
}

\begin{abstract}
Summarv. Hamster spermatozoa, collected from the caput and the cauda of the epididymis, are known to differ in their motility. They do not normally acquire fertilizing ability until they reach the proximal portion of the cauda epididymidis. The aim of the present investigation was to test the fertilizing capacity of spermatozoa from the caput epididymis after initiation. Sperm cells were incubated by adding $10 \mathrm{mM}$ caffeine and 20 30 p. 100 epididymal plasma to the culture medium. Superovulated females were inseminated in utero and the eggs recovered $14 \mathrm{~h}$ after ovulation. In these conditions, $22 \mathrm{p}$. 100 of the ova were fertilized. The possibility that the increased motility of the caput epididymal spermatozoa might reflect an increase in fertilizing ability is discussed.
\end{abstract}

\section{Introduction}

Mammalian spermatozoa are still non-motile upon leaving the testis. They mature progressively during their passage through the epididymis and show increasing motility and capacity for fertility (Orgebin-Crist, 1967 ; Horan and Bedford, 1972 ; Holtz and Smidt, 1976).

In many species some authors have been able to initiate the motility of caput epididymidis spermatozoa by using cAMP phosphodiesterase inhibitors (Garbers et al., 1973 ; Hoskins et al., 1978 ; Dacheux and Paquignon, 1980). Nevertheless, to obtain a forward progression similar to that observed in the cauda epididymidis, it is necessary to add epididymal or seminal plasma into the incubation medium (bull: Hoskins et al., 1975; hamster : Kann and Serres, 1980). Moreover, cinematographic studies by these same authors revealed that some induced sperm movements differ from the corresponding natural ones by the amplitude of the head movements. Is such initiation accompanied by the acquisition of fertilizing ability ? The answer seems to be positive in the guineapig in vivo (Shilon et al., 1978) and in the rabbit in vitro (Brackett et al., 1978), as opposed to the boar (Dacheux and Paquignon, 1980).

The purpose of the present investigation was to test the fertilizing ability of forward-moving spermatozoa from the caput epididymidis after initiation.

\section{Material and methods}

1) Preparation of females. - We used mature 2-month old female hamsters. Superovulation was induced by intraperitoneal injections of 30 IU PMSG in the 
morning (at 10 a.m.) of day 1 (the day of proestrus vaginal discharge), followed by $30 \mathrm{IU} \mathrm{HCG}$ at 2 p.m. on day 3 (Greenwald, 1962). At 6 p.m. on that same day, the females were inseminated as follows : after ether anesthesia, the uterus was exposed through a mid-ventral incision and the sperm suspension $(0.2 \mathrm{ml})$ was injected by advancing a 25-gauge needle into the cervical side of each horn. At 4 p.m. on the following day, the tubal eggs were recovered with the aid of a dissecting microscope. After they were mounted on glass slides beneath a coverslip, the ova were compressed slightly and examined in the fresh state with a phase-contrast microscope at a magnification of $X 100$ or $X 400$ for evidence of sperm penetration.

2) Preparation of sperm suspensions. - Mature 2 to 5 -month old male hamsters were killed by cervical dislocation to prevent sperm cell motility from being affected by the anesthetics. Capita or caudae epididymidis were isolated at room temperature in a $B_{2}$ culture medium (Ménézo, 1976). Sperm suspensions were prepared by mincing either one cauda or 4 capita in $1.5 \mathrm{ml}$ of medium, thus ensuring an adequate number of spermatozoa. The released sperm were filtered through an inox grid. According to the modified method of Kann and Serres (1980), initiated caput epididymidis spermatozoa were obtained by adding $10 \mathrm{mM}$ caffeine and 20 to $30 \mathrm{p} .100$ epididymal plasma to the filtrate. Before insemination, the motility was examined in a drop of the suspension under a phase-contrast microscope. $0.2 \mathrm{ml}$ of the appropriate sperm suspension was injected into the uterine horns of the females.

In each experiment in which initiated caput epididymidis spermatozoa were inseminated, two males were used for two females.

\section{Results}

Freshly ovulated ova appeared surrounded by the cumulus oophorus cells which formed a dense mass constituting the plug. When fertilization occurred, the plug was disaggregated and the oocytes appeared, still isolated in their zona pellucida. In this case, their complete collection was questionable. However, induced ovulation by intraperitoneal injection of 30 IU PMSG made up for this deficiency by increasing the number of oocytes issuing from the ovary $(\bar{x}=20$ oocytes per ovary). If there was no fertilization, the oocytes stayed in the plug, forming a large mass which could be easily seen in the ampulla with the dissecting microscope. The cumulus cells agglutinated to each other either because the spermatozoa present in the vicinity of the eggs were not numerous enough or because they could not undergo the acrosomic reaction and release the enzymes needed to dissociate the cells.

Insemination with cauda epididymidis spermatozoa was followed by 88 p. 100 fertilization of the ova recovered (table 1a). Fourteen hours after fertilization, the oocytes were at the 2-pronuclei stage (plate I, fig. 1). The tail of

PLATE I

Hamster eggs recovered 21 hrs after in utero insemination with cauda epididymidis spermatozoa.

FIG. 1. - Fertilized oocytes in the two-pronuclei stage. $\times 2000$.

FIG. 2. - Fertilizing sperm tail (arrow) is shown in the egg cytoplasm. $\times 2000$. 


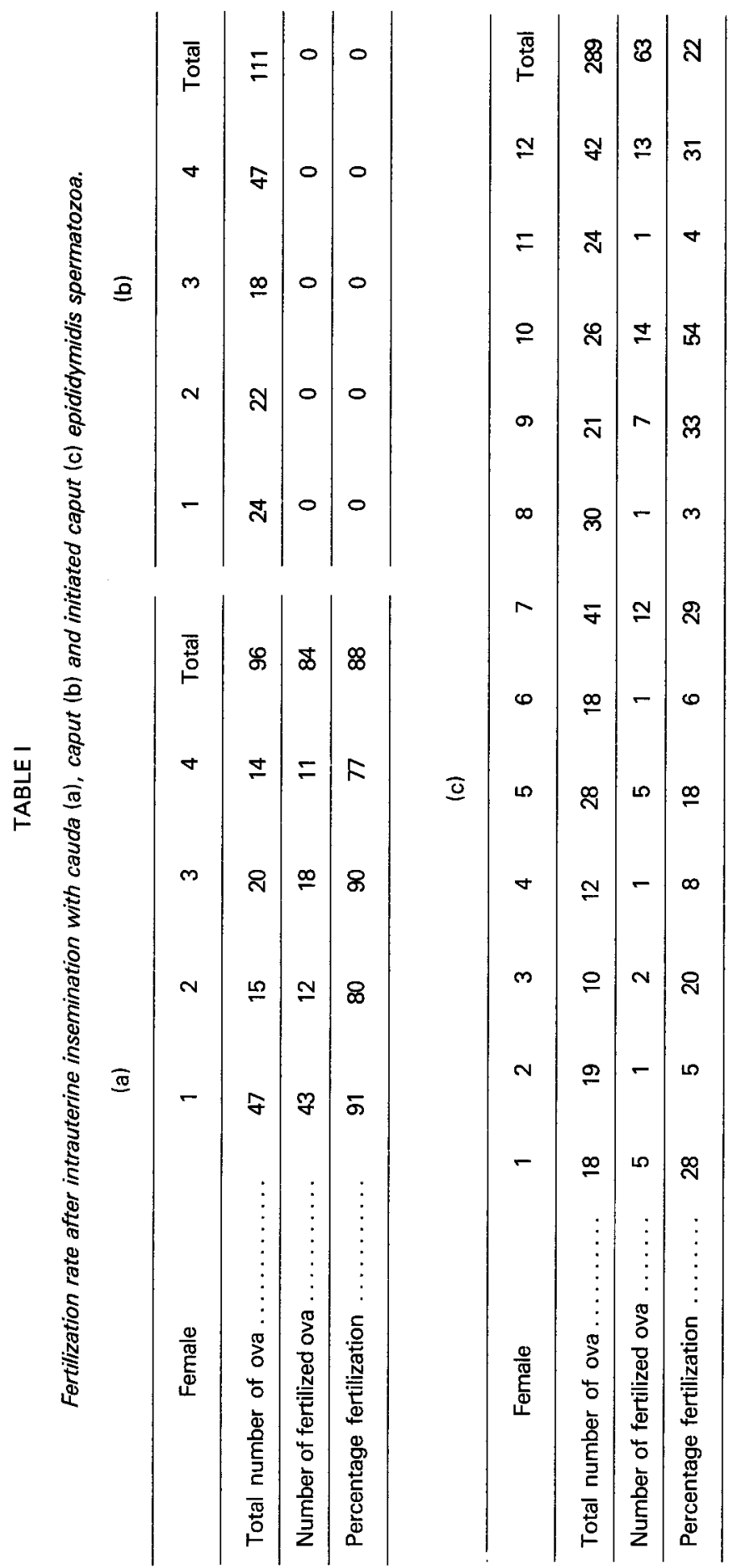


the fertilizing sperm was always found in the egg cytoplasm (plate I, fig. 2). The females inseminated with caput epididymal spermatozoa produced no fertilized eggs (table 1b).

The motility of caput epididymal spermatozoa was initiated after incubation by adding caffeine and epididymal plasma to the medium. Approximately 40 to 50 p. 100 of the sperm cells evaluated at this time by phase-contrast microscopy showed a forward motility pattern identical to that described by Kann and Serres (1980). These spermatozoa were always inseminated within $5 \mathrm{~min}$ after the beginning of incubation. In these conditions, 63 out of 289 ova (22 p. 100) (table 1c) were recovered at the 2-pronuclei stage, the sperm tail always being present (plate II, figs. 1, 2). No abnormality was noticed in these experiments, and we always found a fertilized egg in each female.

Statistical analysis showed that the total number of ova collected in the three groups of females was homogeneous, as was the mean number of ova : $24.0 \pm 5.9,27.8 \pm 5.9$ and $24.1 \pm 3.4$ oocytes collected from the females inseminated with caudal, caput and initiated caput epididymidis spermatozoa, respectively. A great variability (about $50 \mathrm{p} .100$ ) also showed considerable heterogeneity among the females in the three groups. $\chi^{2}$-test analysis clearly demonstrated that the percentage of fertilization was homogeneous for the females inseminated with cauda epididymidis spermatozoa $\left(\chi^{2}=2.6\right.$ for 3 d.f. $)$, but that it was significantly different $\left(\chi^{2}=38.8\right.$ for 11 d.f. ; $\left.P<0.001\right)$ within the females inseminated with initiated caput spermatozoa. This difference may be due to the incomplete maturation of these spermatozoa.

\section{Discussion}

An in vivo approach was used to assess the ability of hamster sperm to fertilize under defined conditions when recovered from various levels of the male reproductive tract. The elevated percentage of fertilization obtained during this experiment shows that cauda epididymal sperm cells in the hamster have reached their capacity to fertilize. These results are in good agreement with those reported by Horan and Bedford (1972). Other studies have also demonstrated this concept in a number of other species ; guinea-pig (Young, 1931), rat (Blandau and Rumery, 1964), rabbit (Nishikawa and Waide, 1952 ; Bedford, 1966 ; Fulka and Kofoed-Johnson, 1966 ; Orgebin-Crist, 1967).

It also appears that spermatozoa from the caput epididymidis have no fertilizing capacity since, as Horan and Bedford (1972) have shown, we obtained 0 . p. 100 fertilization. However, according to the species, the results can be either identical (guinea-pig : 0.p. 100, Shilon et al., 1978) or slightly different (rat : 8 p. 100, Blandau and Rumery, 1964 ; rabbit : 2.1 p. 100, Oregbin-Crist, 1967). These experimental differences can be attributed to a more or less early epididymal maturation process during which motility initiation could be a decisive step in the ability to fertilize. In the hamster, caffeine has a striking effect on motility (Kann and Serres, 1980). This kind of stimulation has also been carried out in caput sperm from rat, guinea-pig, rabbit and bull (Hoskins et al., 1978), boar and ram (Dacheux and Paquignon, 1980). But epididymal plasma is 
necessary to obtain a forward motility and an effect mimicking the change in epididymal sperm during their maturation (Brandt et al., 1978; Kann and Serres, 1980).

Does the increased motility of the initiated caput epididymal spermatozoa reflect an increase in fertilizing ability ? Some results have been found in the guinea-pig after injection of initiated spermatozoa into the peritoneal cavity at $21 \mathrm{~h}$ postpartum (Shilon et al., $1978: 80 \mathrm{p} .100$ ) and in rabbit in vitro (Brackett et al., $1978: 10$ p. 100). On the other hand, no fertilization has been obtained in vivo in the boar (Dacheux and Paquignon, 1980). In the hamster in vivo, the initiation of progressive motility of caput epididymal spermatozoa allows 22 p. 100 fertilization of the ovulated eggs.

It seems that even after satisfactory initiation $(40$ to $50 \mathrm{p.} 100$ of spermatozoa with forward motility), a small number of spermatozoa is present near the cumulus cells at the time of ovulation. The huge superovulated plug is then imperfectly disaggregated. This would explain many cases in which the level of fertilization is low. A better rate should have been recorded without PMSG treatment, but we had to discontinue that technique because of the difficulty in collecting the ova. Besides, we think that we did well to inseminate the initiated spermatozoa within 5 min after contact with the caffeine and epididymal plasma, although in vitro tests have shown that maximal forward progression velocity is attained 20 to $30 \mathrm{~min}$ after the beginning of incubation (Kann and Serres, 1980). Sperm cells initiated in this manner indeed have a good chance of maintaining forward motility until they undergo capacitation, showing a characteristic movement with a greater amplitude of flagellar beating (Yanagimachi, 1970).

These findings indicate that epididymal plasma together with caffeine initiates motility followed by fertilization. However, the experimental conditions only mimic in part the natural ones observed in the cauda epididymidis : 88 p. 100 fertilization vs 22 p. 100 , a percentage which is significantly higher in the cauda epididymidis group than in the initiated caput group $(P<0.001$ with the U-test). Epididymal plasma is composed of many factors necessary to sperm maturation. For example, forward motility protein (FMP) would be involved in the process of motility induction (Hoskins et al., 1978). In our experiments using whole epididymal plasma, we were unable to determine if epididymal motility initiation contributes automatically to the development of the fertilizing capacity or if other components are involved. Initiation by caffeine and purified FMP should answer this question. Experiments with this protein (gift of Dr. Hoskins) are actually being carried out. Another factor involved in the epididymal initiation

\section{PLATE ॥}

Hamster eggs recovered 21 hrs after in utero insemination with initiated caput epididymidis spermatozoa.

FIG. 1. - Normal fertilized egg with two pronuclei. $\times 2000$.

FIG. 2. - The same egg with focalization on the sperm tail. $\times 2000$. 
of motility may be calcium ion. Morton et al. (1978) have shown that hamster epididymal sperm are activated by the addition of calcium. It has recently been suggested by Nelson et al. (1980) that calcium transport is regulated by a cytoplasmic modulator protein, calmodulin, which we intend to study in the future.

Résumé. Les spermatozoïdes de Hamster prélevés dans la tête et la queue de l'épididyme diffèrent par leur motilité. Normalement, ils n'acquièrent leur pouvoir fécondant qu'au niveau de la portion proximale de la queue de l'épididyme. La présente étude a été entreprise afin de tester le pouvoir fécondant des spermatozoïdes de la tête de l'épididyme après initiation. Les spermatozoïdes sont incubés dans un milieu de culture contenant $10 \mathrm{mM}$ de caféine associée à 20-30 p. 100 de plasma épididymaire. Les femelles superovulées sont inséminées in utero et les œufs récupérés $14 \mathrm{~h}$ après l'ovulation. Dans ces conditions on observe 22 p. 100 d'ovocytes fécondés. La possibilité que l'acquisition du pouvoir fécondant est liée uniquement à l'initiation de la motilité dans l'épididyme est discutée.

Reçu en mai 1981.

Accepté en novembre 1981.

\section{References}

BEDFORD J. M., 1966. Development of fertilizing ability of spermatozoa in the epididymis of the rabbit. J. exp. Zool., 163, 319-329.

BLANDAU R. J., RUMERY R. E., 1964. The relationship of swimming movements of epididymal spermatozoa to their fertilizing capacity. Fertil. Steril., 15, 571-579.

BRACKETT B. G., HALL J. L., OH Y. K., 1978. In vitro fertilizing ability of testicular, epididymal, and ejaculated rabbit spermatozoa. Fertil. Steril., 29, 571-582.

BRANDT H., ACOTT T. S., JOHNSON D. J., HOSKINS D. D., 1978 . Evidence for an epididymal origin of bovine sperm forward motility protein. Biol. Reprod., 19. 830-835.

DACHEUX J. L., PAQUIGNON M., 1980. Relations between the fertilizing ability, motility and metabolism of epididymal spermatozoa. Reprod. Nutr. Dévelop., 20, 1085-1099.

FULKA J., KOEFOED-JOHNSON H. H., 1966. The influence of epididymal passage in rabbits on different spermatozoa characteristics including fertilizing capacity. Annu. Rep. roy. vet. agric. Coll., Steril. Res. Inst., Copenhague, 213-225.

GARBERS D. L., FIRST N. L., LARDY H. A., 1973. The stimulation of bovine sperm metabolism by cyclic nucleotide phosphodiesterase inhibitors. Biol. Reprod., 8, 589-598.

GREENWALD G. S., 1962. Analysis of superovulation in the adult hamster. Endocrinology, 71, 378-389.

HOLTZ W., SMIDT D./ 1976. The fertilizing capacity of epididymal spermatozoa in the pig. J. Reprod. Fertil., 46, 227-229.

HORAN A. H., BEDFORD J. M., 1972. Development of the fertilizing ability of spermatozoa in the epididymis of the Syrian hamster. J. Reprod. Fert., 30, 417-423.

HOSKINS D. D., BRANDT H., ACOTT T. S., 1978. Initiation of sperm motility in the mammalian epididymis. Fed. Proc., 37, 2534-2542.

HOSKINS D. D., HALL M. L., MUNSTERMAN D., 1975 . Induction of motility in immature bovine spermatozoa by cyclic AMP phosphodiesterase inhibitors and seminal plasma. Biol. Reprod., 13, 168-176.

KANN M. L., SERRES C., 1980. Development and initiation of sperm motility in the hamster epididymis. Reprod. Nutr. Dévelop., 20, 1739-1749. 
MÉNÉZO Y., 1976. Milieu synthétique pour la survie et la maturation des gamètes et pour la culture de l'œu fécondé. C. R. Acad. Sci. Paris, Sér. D, 282, 1967-1970.

MORTON B. E., SAGADRACA R., FRASER C., 1978. Sperm motility within the mammalian epididymis : species variation and correlation with free calcium levels in epididymal plasma. Fertil. Steril., 29, 695-698.

NELSON L., YOUNG M. J., GARDNER M. E., 1980. Sperm motility and calcium transport : a neurochemically controlled process. Life Sci., 26, 1739-1749.

NISHIKAWA Y., WAIDE Y., 1952. Studies on the maturation of spermatozoa. I. Mechanism and speed of transition of spermatozoa in the epididymis and their functional changes. Bull. nat. Inst. agr. Sci., Ser. G, $\mathrm{N}^{\circ} 3,68-78$.

ORGEBIN-CRIST M. C., 1967. Maturation of spermatozoa in the rabbit epididymis : fertilizing ability and embryonic mortality in does inseminated with epididymal spermatozoa. Ann. Biol. anim. Bioch. Biophys., 7, 373-389.

SHILON M., PAZ G., HOMONNAI Z. T., SCHOENBAUM M., 1978. The effect of caffeine on guinea pig epididymal spermatozoa : motility and fertilizing capacity. Internat. J. Androl., 1. 416-423.

YANAGIMACHI R., 1970. The movement of golden hamster spermatozoa before and after capacitation. J. Reprod. Fert., 23, 193-196.

YOUNG W. C., 1931. A study of the function of the epididymis. III. Functional changes undergone by spermatozoa during their passage through the epididymis and vas deferens in the guinea pig. J. exp. Biol., 8, 151-162. 